\title{
PENENTUAN HARGA POKOK GABAH: ANALISIS BERDASARKAN MUSIM TANAM
}

\author{
Ni Ketut Sriwinarti, Uswatun Hasanah \\ Akuntansi Universitas Bumigora \\ ${ }^{1}$ sriwinarti@stmikbumigora.ac.id, ${ }^{2}$ uswatun@stmikbumigora.ac.id
}

\begin{abstract}
Abstrak
Penelitian ini bertujuan untuk meningkatkan kemandirian dalam pengelolaan keuangan khususnya dalam penentuan harga pokok penjualan gabah. Di dalam memperoleh data penelitian, peneliti terlibat langsung mulai dari proses olah tanah, tanam hingga panen. Penelitian ini dimulai dari bulan Februari sampai dengan September 2018. Lokasi penelitian Lokasi kegiatan berada di Desa Jago, Kecamatan Praya Lombok Tengah. Terdapat 4 (empat) petani yang diajdikan objek penelitian yaitu pertama petani yang memiliki lahan 52 are, kedua petani yang memiliki lahan 47 are, ketiga petani yang memiliki lahan 58 are dan terakhir petani yang memiliki lahan 42 are. Dari hasil pengamatan ditemukan bahwasanya pada musim tanam kedua masalah air menjadi masalah utama dalam mempengaruhi hasil tanam, dimana rata-rata petani mengalami penurunan hasil, namun dengan Penggunaan teknologi tanam jarwo terbukti memiliki hasil yang lebih banyak bila dibandingkan dengan metode tanam biasa. biaya keseluruhan yang dikeluarkan dalam memperoleh gabah basah atau harga pokok gabah basah yaitu berkisar antara Rp.1.560/kg hingga Rp.1.884/kg, untuk memperoleh gabah kering masih harus dilakukan penjemuran kembali yang memakan waktu kurang lebih satu minggu tergantung factor cuaca.
\end{abstract}

Kata Kunci : Harga Pokok Gabah, Akuntansi Padi,

\section{PENGANTAR}

\section{Latar Belakang}

Beras bukan hanya menjadi kebutuhan utama di masyarakat Indonesia akan tetapi sudah merupakan komoditi social ekonomi dan mempunyai peran dalam stabilitas politik. Sehingga tak jarang perubahan-perubahan yang terjadi pada beras dapat mempengaruhi kehidupan ekonomi-politik di Indonesia, sehingga tak jarang pemerintah berupaya untuk menstabilkan harga beras dipasaran terutama saat panen raya (Mandei et all, 2011).

Salah satu cara yang dilakukan Pemerintah untuk menstabilkan harga dipasaran adalah dengan menetapkan harga pembelian pemerintah (HPP) melalui Instruksi Presiden Republik Indonesia (INPRES) Nomor 5 Tahun 2015, diketahui bahwa HPP gabah kering panen di tingkat petani adalah sebesar Rp. 3.700,- per kilonya naik sebesar Rp.400,- dari ketetapan tahun sebelumnya. Selain itu di dalam INPRES Nomor 5 tahun 2015 juga terdapat klausa yang menyatakan bahwa Bulog akan melakukan pembelian atas gabah kering giling dengan harga Rp.4.600 dan Rp.7.300. Namun berdasarkan hasil wawancara yang dilakukan dengan para petani diperoleh informasi bahwasanya mayoritas para petani tidak tahu mengenai kebijakan pemerintah mengenai harga beli yang diterima oleh BULOG dan bagaimana cara melakukan transaksinya, selain itu kebanyakan para petani menjual tanaman padi dengan hitungan per are sedangkan proses ngerampek ${ }^{l}$ dilakukan oleh para tengkulak sehingga para petani hanya berpaku terhadap penawaran dari para tengkulak/saudagar. ketidakpastian akan berapa hasil inilah yang kemudian membuat petani menjadi kurang mandiri. Bapak Sahrun salah satu saudagar yang digali informasinya

\footnotetext{
${ }^{1}$ Ngerampek merupakan istilah yang digunakan oleh para petani suku sasak pada saat proses pelepasan bulir padi dari tanamannya
} 
mengungkapkan bahwa penentuan harga beli yaitu berdasarkan perasaan atau pengalaman pada saat melihat padi disawah, tapi kepastian akan untung atau rugi akan diketahui apabila sudah dirampek karena adanya ketidakpastian hasil maka sering kali para saudagar akan memberikan harga jauh lebih rendah dari yang seharusnya

Kabupaten Lombok Tengah memiliki luas panen padi terluas di Nusa Tenggara Barat yaitu seluas 72.534 hektar, namun dari hasil data statistic diketahui pula bahwa diantara kabupaten-kabupaten yang berada di wilayah Nusa Tenggara Barat, kabupaten Lombok tengah ternyata memiliki persentase tertinggi dalam menghasilkan gabah dengan kualitas rendah sehingga harga penawarannya yang diberikan pun relative lebih rendah apabila dibandingkan dengan kabupaten yang lain (BPS NTB, 2018)., hal inilah yang kemudian memunculkan pertanyaan lebih lanjut yaitu berapa sesungguhnya biaya yang dikeluarkan oleh para petani untuk menghasilkan gabah atau beras di wilayah Lombok Tengah, apakah para petani diwilayah ini rugi atau untung. Sumodiingrat (1987), mengungkapkan biaya adalah pengeluaranpengeluaran yang dilakukan dalam usaha untuk menyelesaikan proses produksi. Biaya yang dikeluarkan oleh seorang petani dalam proses produksi serta membawanya menjadi suatu produk disebut biaya produksi ( Hernanto, 1989). Menurut Djodjodiputro (1991) biaya adalah pengeluaran dalam bentuk proses produksi yang tidak dapat dihindarkan, sedangkan menurut Soekartiwi (1995), biaya usahatani adalah semua pengeluaran yang dipergunakan dalam suatu usahatani.

Sriwinarti (2016) mengungkapkan bahwasanya pola penanaman padi ternyata berdampak terhadap mutu hasil yang diperoleh, dimana antara sawah yang satu dengan sawah yang lain walaupun sama-sama menanam padi namun memiliki biaya yang berbeda selain itu jumlah gabah yang dihasilkan pun kadang jauh berbeda. Hasil padi yang diperoleh sangat bergantung dari varietas apa yang ditanam, bagaimana menanamnya, bagaimana mengendalikan ph tanah, dan bagaimana serta kapan pemupukan dilakukan. Cara berbeda, biaya yang dikeluarkan pun berbeda apabila petani kurang berhati-hati maka biaya yang dikeluarkan akan menjadi besar dan hasil yang diperoleh juga bisa kurang optimal

Berdasarkan hal tersebut, peneliti berharap adanya informasi seperti pengelolaan dana yang dimiliki dimana didalamnya terdapat perhitungan yang jelas mulai dari jenis bibit yang ditanam, biaya penanaman, biaya sistem pengairan, biaya pemupukan, pengobatan hingga penggilingan sehingga diperoleh nilai pasti dari harga pokok gabah yang dihasilkan. Kegiatan pemantauan harga gabah, bertujuan untuk memperoleh informasi dan memberikan data mengenai perbedaan harga berdasarkan wilayah, komponen mutu gabah dan harga bila dibandingkan harga pembelian pemerintah. Hasil pemantauan ini diharapkan sebagai sistem peringatan dini bagi instansi pemerintah terkait untuk menentukan langkah antisipatif dalam rangka pengamanan harga gabah.

\section{Perumusan Masalah}

Desa Jago merupakan salah satu desa yang berada di Kecamatan Praya Kabupaten Lombok Tengah., dimana beberapa petaninya tidak melakukan pencatatan terhadap berapa biaya yang dikeluarkan selama proses pertumbuhan padi. ketidak adanya pembukuan yang dilakukan oleh para petani menyebabkan para petani tidak pasti akan berapa biaya yang dikeluarkan yang mana hal ini berdampak pada sulitnya dalam menentukan harga pokok penjualan gabah. Oleh karena itu yang menjadi permasalahan dalam penelitian ini adalah bagaimana model laporan harga pokok gabah? dan apakah harga gabah yang ditetapkan pemerintah berada dibawah biaya produksi gabah?

\section{Tujuan dan manfaat penelitian}

Penelitian ini bertujuan untuk mengetahui:

1) Harga pokok penjualan gabah di Desa Jago Kecamatan Praya Kabupaten Lombok Tengah NTB 
2) Membandingkan harga pokok penjualan dengan harga pasar dan harga pembelian pemerintah (HPP)

Adapun manfaat dari penelitian ini adalah memberikan informasi dan pengetahuan bagi pembaca dan semua pihak yang membutuhkan.

\section{METODE PENELITIAN}

\section{Metode Pengumpulan Data}

Penelitian ini menggunakan metode survey dengan melibatkan 2 kelompok petani, dimana masing-masing kelompok tani diambil 2 orang petani sehingga total petani/responden yang digunakan dalam penelitain ini adalah 4 (empat) orang petani.

\section{Metode Pengambilan Sampel}

Penentuan lokasi dilakukan secara sengaja (purposive sampling) dimana pada penelitian ini team peneliti lakukan mulai bulan februari 2018 sampai bulan September 2018. Lokasi kegiatan berada di Desa Jago, Kecamatan Praya Kabupaten Lombok Tengah, lahan yang digunakan sebagai lokasi penelitian adalah sebanyak 4 (empat) lahan yaitu dengan: (1) luas 52 are; (2) seluas 47 are ; (3) 42 are dan satunya lagi seluas 58 are.

\section{Konsep Pengukuran Variabel}

Variabel yang akan diukur dalam penelitian ini, yaitu:

1) Luas lahan padi sawah (ha)

2) Biaya yang akan dikeluarkan mulai dari: Proses Olah Tanah
a) Proses Pembibitan
b) Proses Penanaman
c) Proses Pemupukan
d) Proses Panen
e) Proses Giling

\section{Analisis Data}

Data yang diperoleh akan disajikan dalam bentuk tabel dan dianalisis secara deskriptif. Untuk menghitung harga pokok penjualan gabah per kg digunakan rumus:

Harga pokok penjualan per $\mathrm{kg}=\frac{\text { Jumlah Biaya Yang dikeluarkan }(\mathrm{Rp})}{\text { Jumlah Produksi yang dihasilkan }(\mathrm{kg})}$

\section{HASIL DAN PEMBAHASAN}

\section{Biaya Berdasarkan Tahapan Produksi Padi \\ Olah Tanah}

Proses olah tanah dapat dilakukan dengan 2 (dua) cara yaitu satu dengan alat tradisional dimana binatang sapi/kerbau sebagai penariknya sedangkan satu lagi adalah dengan menggunakan mesin traktor. Untuk lahan yang peneliti jadikan obyek penelitian, keseluruhan para petani mengolah tanahnya dengan menggunakan mesin traktor, ketika peneliti melakukan penggalian data, diperoleh informasi bahwasanya sudah sangat jarang sekali para petani menggunakan alat tradisional dengan binatang sapi atau kerbau sebagai penggeraknya. Dari hasil wawancara dengan salah satu petani dikatakan bahwasanya biaya untuk 
memelihara sapi cukup mahal selain itu rawan hilang "lelah ite bejage nane" merupakan ungkapan yang disampaikan oleh Bapak Harun.

Pembayaran untuk membajak sawah terbagi menjadi dua metode yaitu membayar dengan menggunakan uang tunai atau dengan menggunakan gabah kering. Untuk satu bangketan ${ }^{2}$ Pak sarka memberikan setengah timbang gabah kering jumlah gabah yang diberikan adalah 1,75 timbang gabah kering atau $175 \mathrm{~kg}$ gabah kering yang apabila dirupiahkan maka akan menjadi Rp. 805.000 (1 kg gabah kering sama dengan Rp.4600). sedangkan lahan Bapak Harun dibayarkan biaya Rp 20.000/are. sedangkan tanah yang dikelola bersama H. Sapoan dibayarkan Rp. 17.000/are. Biaya yang dikeluarkan belum termasuk rokok rata-rata sebanyak 2 bungkus dengan harga Rp. 15.000/bungkus (rata-rata rokok yang dibeli adalah rokok surya 12), makanan dan minuman yang apabila di jumlahkan maka tambahan biaya yang dikeluarkan untuk konsumsi adalah sebesar Rp. 100.000,-. Jika diambil sebuah kesimpulan, maka biaya untuk mengolah sawah dibutuhkan adalah Rp.17.000,- hingga Rp.18.000,- perbedaan biaya yang terjadi disebabkan karena adanya biaya tambahan berupa konsumsi ataupun karena akses jalan kelahan. apabila dibuat rekapan maka biaya yang dikeluarkan oleh masing-masing responden adalah :

\section{Tabel 1. Biaya Olah Tanah}

$\begin{array}{lllll}\text { No } & \text { Nama Petani } & \text { Luas Lahan } & \text { Total Biaya } & \text { Biaya Per are } \\ 1 & \text { Bapak H. Harun } & 52 \text { are } & \text { Rp. } 996.000,- & \text { Rp. } 19.153,84 \\ 2 & \text { Bapak Sarka } & 47 \text { are } & \text { Rp. } 865.000,- & \text { Rp. } 18.404,25 \\ 3 & \text { Bapak H. Sapoan } & 58 \text { are } & \text { Rp. } 1.000 .000,- & \text { Rp. } 17.241,37 \\ 4 & \text { Bapak Sadiah } & 42 \text { are } & \text { Rp. } 750.000,- & \text { Rp. } 17.857,14\end{array}$

\section{Pembibitan}

Pembibitan dilakukan pada musim jeda, dimana petani akan mengolah sendiri satu petak tanahnya untuk menanam benih/bibit padi. Pertama tanah akan dibuat gembur dan diberikan air hingga tanah menjadi lembab atau agak berlumpur kemudian dibuatkan bedengan yang lebarnya biasanya antara 1.5 - 2 meter. Benih padi sebelum ditanam direndam terlebih dahulu selama satu malam. Setelah lahan siap kemudian benih padi yang telah direndam sebelumnya ditaburkan ke lahan secara merata. Tidak ada metode atau teori cara menyebarkan benih padi, hal utama yang perlu diperhatikan adalah anda menaburkan benih padi ke bedengan secara rata.

Untuk menanam padi pada Lahan Bapak Harun yang seluas 52 are dibutuhkan bibit sebanyak 2 kantong $1 / 2$ atau sebanyak $25 \mathrm{~kg}$ bibit namun karena kemasan bibit adalah $10 \mathrm{~kg} / \mathrm{kantong}$ sehingga peneliti membeli 3 kantong bibit yang sisanya disimpan untuk ditanam periode berikutnya. Harga perkantong bibit padi dengan label ungu adalah Rp. 90.000/kantong. Sedangkan Bapak sarka menggunakan 20 kilo bibit padi, namun sayang karena lahan pak sarka dekat dengan perkampungan sehingga beberapa bibitnya yang baru tumbuh rusak oleh ayam dan anjing liar. Sehingga untuk menanam lahan seluas 42 are, pak sarke harus membeli tambahan bibit sebanyak 2 (dua) pongos. Satu pongos sama dengan 20 ikat bibit tanaman padi yang dibayarkan perpongos adalah Rp. 50.000,-. Bapak H. Sapoan walaupun memiliki lahan yang lebih luas, juga menanam bibit dengan jumlah yang sama dengan Bapak Nurdin, sedangkan Amaq Sadiah menggunakan $15 \mathrm{~kg}$ bibit atau satu setengah kantong.

\footnotetext{
${ }^{2}$ Bangketan adalah satu petak lahan sawah yang setiap petaknya memiliki luas yang berbeda-beda yaitu antara 10 sampai dengan 16 are
} 
Setelah bibit padi berumur 2 minggu atau sudah dianggap cukup tinggi, kemudian dilakukan pencabutan, pada saat melakukan pencabutan, tangan dimasukkan sedikit ketanah agar akarnya dapat tercabut semuanya. Kemudian bibit padi yang telah dicabut diikat menjadi satu, jumlah pohon padi pada satu ikatan tidak sama dengan ikatan yang lain, banyak sedikitnya jumlah pohon padi dalam satu ikatan tergantung dari perasaan/kenyaman tukang cabut. Satu ikatan biasanya sebesar satu pegangan tangan orang dewasa atau seperti pada gambar 6.c diatas. Setelah selesai di cabut, tanah tempat menyemai bibit padi kemudian diolah kembali agar bisa ditanami. Dari hasil bibit padi yang disemai oleh Bapak Nurdin dihasilkan \pm 427 ikatan padi., jumlah ini bisa bertambah karena ada beberapa bagian yang tidak dijabut semuanya, biasanya akan digunakan sebagai pengganti jika bibit padi yang ditanam ada yang mati atau kurang pertumbuhannya. Apabila dibuatkan rekapan biaya maka biaya yang dikeluarkan untuk menyemai padi adalah:

Tabel 2. Biaya Pembibitan Padi

$\begin{array}{lllll}\text { No } & \text { Nama Petani } & \text { Luas Lahan } & \text { Total Biaya } & \text { Biaya Per are } \\ 1 & \text { Bapak H. Harun } & 52 \text { are } & \text { Rp. } 225.000 & \text { Rp. } 4.326,92 \\ 2 & \text { Bapak Sarka } & 47 \text { are } & \text { Rp. } 280.000 & \text { Rp. } 5.957,44 \\ 3 & \text { Bapak H. Sapoan } & 58 \text { are } & \text { Rp. } 225.000 & \text { Rp. } 3.879,31 \\ 4 & \text { Bapak Sadiah } & 42 \text { are } & \text { Rp. } 135.000 & \text { Rp. } 3.214,28\end{array}$

Apabila melihat data biaya pada tabel di atas terlihat bahwasnya biaya yang di keluarkan oleh Bapak Sarka sangat tinggi, namun besarnya biaya ini disebabkan adaanya beberapa bibit pohon tanaman padinya yang rusak akibat factor eksternal (dimakan ayam/di rusak anjing liar). Namun apabila dilihat dari hasil lapangan maka dapat diketahui bahwasanya biaya yang dikeluarkan untuk bibit padi adalah sebesar Rp.3500 - Rp. 4000,- per arenya.

\section{Penanaman}

Cara tanam jajar legowo merupakan salah satu teknologi yang dapat meningkatkan populasi tanaman per satuan luas yang diharapkan secara signifikan meningkatkan produktivitas padi sawah (Badan Litbang Pertanian, 2009). Ikhwani et al., (2013) menyatakan bahwa sistem tanam legowo pada prinsipnya memanipulasi tata letak tanaman sehingga sebagian besar tanaman menjadi tanaman pinggir. Sistem tanam jajar legowo dikembangkan dari sistem tanam tegel yang telah berkembang di Masyarakat.Kata Legowo berasal dari bahasa Jawa Banyumas yang artinya lego=luas dan dowo=memanjang. Teknologi ini dikembangkan untuk mendapatkan border effect yang lebih banyak (Pahruddin, Maripul and Philips, 2004). Berkaitan dengan border effect, (Mohaddesi et al., 2011) menyatakan bahwa tanaman yang berada pada barisan pinggir memperoleh sinar matahari secara maksimal sehingga proses fotosintesis juga berlangsung secara optimal, serta persaingan hara antar tanaman semakin rendah. Menurut (Wang et al., 2013) efek pinggir memberikan pengaruh terhadap lebih tingginya produksi biomassa, lebih banyaknya malai per satuan luas dan lebih tingginya persentase gabah isi. Pak Busro yang merupakan petugas pertanian juga menjelaskan bahwasanya dengan adanya jarak juga sangat memudahkan ketika pemberian pupuk dan obat-obatan. Namun beberapa petani masih belum sepenuhnya menerima, mereka beranggapan selain tambah repot juga berangapan adanya banyak jarak 
kososng yang seharusnya bisa dimanfaatkan. Untuk metode jarwo, terdapat 2 fenomena yang ditemukan dilapangan, pertama jika daerah tersebut memiliki air yang melimpah, biasanya para petani tidak takut akan mengeluarkan air disawah untuk dibuatkan garis oleh "tukang garis" sedangkan jika lahan yang sulit mendapatkan air dan kebetulan tanahnya sudah diairi maka digunakanlah tali sebagai pembatas untuk menanam. Dimana biaya garis dikenakan Rp.20.000/bangketan, namun terkadang petani menggaris sendiri lahannya dengan menggunakan kayu yang sudah dimodifikasi dimana jarak yang dibuat adalah satu jengkal tangan orang dewasa atau bekisar antara $15 \mathrm{~cm}-20 \mathrm{~cm}$., sedangkan jika menggunakan tali dapat digunakan tali raffia (Rp. 15.000/0.5kg) atau tali pemancu (Rp. $35.000 / \mathrm{kg}$ )

Apabila telah digaris langkah selanjutnya adalah menanam padi, terdapat kelompok-kelompok buruh tanam padi yang terdiri atas 10 - 15 orang yang mana mayoritas dari buruh tanam ini adalah perempuan. Satu orang buruh diupah Rp.25.000 - Rp.30.000., dikarenakan pertimbangan keberadaan kelompok buruh tanam inilah yang kemudian membuat dilema pengabdi dilapangan sehingga pengabdi membatalkan menggunakan mesin tanam padi dan tetap menggunkan kelompok tanam dalam mengerjakan lahan bersama mitra.

Waktu pengerjaan menanam pohon padi ini biasa tergantung dari permintaan si pemilik lahan, namun rata-rata proses pengerjaan menanam ini dimulai dari subuh dan akan selesai pada tengah hari.

\begin{tabular}{|c|c|c|c|c|}
\hline \multirow[b]{2}{*}{ No } & \multirow[b]{2}{*}{ Nama Petani } & \multicolumn{2}{|c|}{ Tabel 3. Biaya Tanam Padi } & \multirow[b]{2}{*}{ Biaya Per are } \\
\hline & & Luas Lahan & Total Biaya & \\
\hline 1 & Bapak H. Harun & 52 are & Rp. 435.000,- & Rp. $8.365,38$ \\
\hline 2 & Bapak Sarka & 47 are & Rp. 410.000,- & Rp. $8.723,40$ \\
\hline 3 & Bapak H. Sapoan & 58 are & Rp. 455.000,- & Rp. $7.844,82$ \\
\hline 4 & Bapak Sadiah & 42 are & Rp. $250.000,-$ & Rp. 5.952,38 \\
\hline
\end{tabular}

\section{Pemupukan dan Pengobatan}

Pemupukan dilakukan sebanyak 2 (dua) kali yaitu pertama dilakukan setelah 15 hari dari penanaman, pemberian pupuk ini merupakan hal yang sangat penting dalam membantu pertumbuhan padi sedangkan pemupukan kedua dalam istilah para petani adalah pupuk "balas" yang artinya pupuk pelengkap untuk tanaman padi yang apabila pertumbuhannya tidak rata. Ketidak rataan pertumbuhan tersebut biasanya disebabkan karena pada saat awal pupuk tidak terkena atau mendapatkan pupuk lebih sedikit. Pemupukan kedua dilakukan setelah 25 hari dari pemupukan pertama. Apabila berdasarkan pedoman dari RDKK yang disusun petugas penyuluh lapangan (PPL) dan disahkan oleh kepala lurah atau desa setempat maka terdapat 5 jenis pupuk yang digunakan oleh petani yaitu pupuk UREA, Pupuk Sp-36, Pupuk NPK (ponska), pupuk ZA, dan pupuk oraganik namun kebanyak para petani hanya menggunakan 3 jenis pupuk yaitu pupuk urea, Pupuk Ponska dan pupuk SP 36 yaitu dengan takar $1: 0.5$ yaitu untuk 50 are untuk pemupukan pertama membutuhkan $50 \mathrm{~kg}$ urea dan masing-masing $25 \mathrm{~kg}$ ponska dan $25 \mathrm{~kg}$ SP. Harga 1 sak urea (50kg) adalah Rp. 95.000., sedangkan Sp-36 adalah Rp 115.000 dan ponska Rp. 110.000 .

Proses pemupukan pertama tidak menghadapi kendala dikarenakan air masih sangat melimpah. Kekhawatiran petani saat pemupukan pertama adalah serangan keong yang biasanya akan banyak muncul ketika adanya genangan air, oleh sebab itu berdasarkan saran petugas lapangan, pupuk yang akan ditabur 
dicampurkan dengan $8 \mathrm{~kg}$ obat keong, biaya obat tergantung dari merk obat yang digunakan kisaran harga adalah Rp. 35.000,- sampai Rp. 55.000,-.

Pada saat pemupukan kedua, permasalahan air menjadi permasalahan utama yang dihadapi oleh para petani, dimana musim kemarau terlalu awal untuk tahun ini sehingga proses pemupukan kedua menjadi tertunda dikarenakan menunggu keberadaan air. Desa Jago kecamatan Praya merupakan desa yang lahannya berada didaerah ketinggian sehingga apabila musim kemarau tiba maka air disumurpun ikut kering. Terkadang untuk mendapatkan air para petani harus bersedia mengeluarkan uang lebih sebagai ucapan terima kasih kepada Pekasih (petugas air) agar bersedia membukakan pintu air. Pada saat ini muncul kekhawatiran akan gagalnya panen, hal ini dikarenakan beberapa sawah lain padi-padi yang ditanam sudah mulai mengering. Sehingga untuk mengurangi resiko akan gagalnya panen, berdasarkan instruksi dari petugas lapangan, begitu lahan sudah mendapatkan air selain diberikan pupuk tambahan, tanaman juga disemprotkan obat-obatan seperti, obat pengisi biji, obat ulat dan obat penyakit daun merah. Besarnya biaya yang dikeluarkan pada proses ini diakibatkan karena kurang sehatnya tumbuhan padi yang sebabkan oleh factor alam terutam air.

Tabel 4. Biaya Pemupukan dan Pengobatan

\begin{tabular}{|c|l|c|c|c|c|c|}
\hline No & \multicolumn{1}{|c|}{ Nama Petani } & $\begin{array}{c}\text { Luas } \\
\text { Lahan }\end{array}$ & $\begin{array}{c}\text { Biaya } \\
\text { Pupuk }\end{array}$ & Biaya Obat & Total Biaya & Biaya Per are \\
\hline 1 & Bapak H. Harun & 52 are & $415,000.00$ & $715,000.00$ & $1,130,000.00$ & $21,730.77$ \\
\hline 2 & Bapak Sarka & 47 are & $415,000.00$ & $685,000.00$ & $1,100,000.00$ & $23,404.26$ \\
\hline 3 & Bapak H. Sapoan & 58 are & $605,000.00$ & $770,000.00$ & $1,375,000.00$ & $23,706.90$ \\
\hline 4 & Bapak Sadiah & 42 are & $415,000.00$ & $630,000.00$ & $1,045,000.00$ & $24,880.95$ \\
\hline
\end{tabular}

\section{Panen}

Berdasarkan hasil dilapangan ditemukan bahwasanya terdapat 3 metode atau cara yang digunakan untuk memanen hasil sawah yaitu pertama dengan menggunakan mesin panen yang kedua menggunakan alat modifikasi perontok gabah dan ketiga dengan cara tradisional yaitu dengan memukul-mukulkan tanaman padi ke papan sehingga bulir-bulir padi dapat terlepas dari pohonnya. Untuk biaya panen relative sama walaupun menggunakan 3 metode yaitu perbandingan 10:1, hanya saja waktu yang di butuhkan yang berbeda-beda.

Untuk musim kedua para petani mengalami kesulitan air sehingga terjadi keterlambatan dalam pemupukan yang terpengaruh terhadap hasil panen yang dihasilkan dimana untuk sawah pak Sarka saja yang biasanya menghasilkan 3,5 ton sekarang hanya menghasilkan 2,2 ton sedangkan pak Harun juga mengalami penurunan yaitu hanya menghasilkan 2 ton saja sedangkan amag sadiah hanya menghasilkan 1,7 ton.

Harga pertimbang gabah basah jika dijual ke pengerampek langsung saat ini dihargai Rp. 410.000 - Rp. 420.000 harga ini masih tidak mengalami kenaikan bila dibandingkan panen musim lalu., jika beruntung maka bisa dijual dengan harga Rp. 430.000,- jika gabah kering dapat di jual dengan harga Rp. 460.000 amaq sapoan sangat beruntung kali ini dimana tanaman padi yang ditanam seluas 58 are dihargai Rp. 13.700.000,- dimana dirinya menjual langsung ke saudagar. Dimana kerugian saudagar yang diketahui adalah sebesar kurang lebih Rp. 1.000.000,-

Untuk musim kedua para petani mengalami kesulitan air sehingga terjadi keterlambatan dalam pemupukan yang terpengaruh terhadap hasil panen yang dihasilkan dimana untuk sawah pak Sarka saja yang biasanya menghasilkan 3,5 ton sekarang hanya menghasilkan 2,3 ton sedangkan pak Nurdin yang lahannya paling berdampak akan kekeringan juga mengalami penurunan hasil walaupun tidak sebesar 
penurunan bapak Sarka yaitu dari 2.98 ton menjadi 2.1 ton saja sedangkan amag sadiah hanya menghasilkan 1,7 ton dari sebelumnya 2.5 ton.

\section{Harga Pokok Gabah}

Melalui pencatatan biaya produksi yang dilakukan, peneliti kemudian dapat menyusun Harga Pokok Gabah Per petani yaitu:

Tabel 5

Harga Pokok Gabah

\begin{tabular}{|c|c|c|c|c|c|c|c|c|}
\hline \multirow{2}{*}{\begin{tabular}{|c|}
\multicolumn{2}{|c}{ Keterangan } \\
Harga Pokok Gabah \\
\end{tabular}} & \multicolumn{2}{|c|}{ Sawah seluas 52 are } & \multicolumn{2}{|c|}{ Sawah Seluas 47 are } & \multicolumn{2}{|c|}{ Sawah seluas 58 are } & \multicolumn{2}{|c|}{ Sawah Seluas 42Are } \\
\hline & & & & & & & & \\
\hline Biaya Bahan Baku (Bibit) & & $225,000.00$ & & $280,000.00$ & & $225,000.00$ & & $135,000,00$ \\
\hline \multicolumn{9}{|l|}{ Biaya Pertumbuhan Padi } \\
\hline Biaya Olah Tanah & $996,000.00$ & & $750,000.00$ & & $1,000,000.00$ & & $750,000.00$ & \\
\hline Biaya Tanam & $435,000.00$ & & $410,000.00$ & & $455,000,00$ & & $250,000,00$ & \\
\hline Biaya Pemupukan & $415,000.00$ & & $415,000.00$ & & $605,000,00$ & & $415,000.00$ & \\
\hline Biaya Pengobatan & $715,000,00$ & & $685,000,00$ & & $770,000,00$ & & $630,000,00$ & \\
\hline Biaya Air & $300,000,00$ & & - & & $250,000.00$ & & $200,000,00$ & \\
\hline Biaya Panen & $886,200,00$ & & $936,600,00$ & & $1,053,360,00$ & & $714,000,00$ & \\
\hline Total Biaya Pertumbuhan Padi & & $3,747,200.00$ & & $3,196,600.00$ & & $4,133,360.00$ & & $2,959,000,00$ \\
\hline Harga Pokok Gabah & & $3,972,200.00$ & & $3,476,600.00$ & & $4,358,360.00$ & & $3,094,0000,00$ \\
\hline Hasil & & $2108 \mathrm{~kg}$ & & $2228 \mathrm{~kg}$ & & $2508 \mathrm{~kg}$ & & $1700 \mathrm{~kg}$ \\
\hline HPP $/ \mathrm{kg}-\cdots$ & & $1,884.35$ & & $1,560.41$ & & $1,737.78$ & & $1,820.00$ \\
\hline
\end{tabular}

Berdasarkan tabel diatas diketahui bahwasanya harga pokok gabah berkisar antara Rp.1.506,41 Rp.1.884,35 perkg nya. Sehingga apabila kita melihat biaya yang dikeluarkan oleh para petani pada prinsipnya harga yang diberikan oleh pasar sudah cukup menguntungkan walapun masih dibawah harga yang ditetapkan pemerintah.

\section{Kesimpulan}

Berdasarkan hasil di atas, dapat disimpulkan beberapa hal yaitu:

1) Biaya yang dikeluarkan oleh masing-masing petani berbeda-beda hal ini dipengaruhi oleh luas tanah, factor lingkungan dan metode pembayaran yang dipilih

2) Total biaya yang dikeluarkan pada lahan yang dikelola pak Harun adalah sebesar Rp. 3.972.200 dimana hasil yang diperoleh adalah sebanyak $2.108 \mathrm{~kg}$ gabah hal ini berarti biaya gabah basah milik pak Nurdin adalah Rp. 1.884,35

3) Total biaya yang dikeluarkan pada lahan yang dikelola bersama Pak Sarka adalah Rp. 3.476.600., dimana hasil yang diperoleh adalah sebanyak $2.228 \mathrm{~kg}$ hal ini berarti biaya yang dikeluarkan untuk memperoleh gabah basah adalah Rp.1.560,41/kg

4) Total biaya yang dikeluarkan pada lahan yang dikelola bersama Amaq Sadiah adalah Rp. 3.094.000,- dimana hasil yang diperoleh adalah 1.7 ton. Hal ini berarti biaya yang dikeluarkan untuk memperoleh gabah basah adalah Rp. 1.820,-/kg 
5) Penggunaan metode tanam jarwo terbukti sangat membantu para petani dalam hal pemberian obat dan pupuk, selain itu metode tanam jarwo 4:1 dan 5:1 terbukti memiliki hasil yang lebi banyak bila dibandingkan dengan metode tanam biasa.

\section{REFERENSI}

Ikhwani et al. (2013) 'Peningkatan produktivitas padi melalui penerapan jarak tanam jajar legowo', Iptek Tanaman Pangan, 8(2), pp. 72-79.

Instruksi Presiden Republik Indonesia Nomor 3 Tahun 1999 Tentang Pembaharuan Kebijaksanaan Pengelolaan Irigasi

Instruksi Presiden Republik Indonesia Nomor 5 Tahun 2015 Tentang Kebijakan Pengadaan Gabah/Beras Dan Penyaluran Beras Oleh Pemerintah

Kartika, et. al., 2018, Internal Versus Edge Row Comparison in Jajar Legowo 4:1 Rice Planting Pattern at Different Frequency of Fertilizer Applications, ARIVITA Journal of Agricultural Science. 2018. 40(2): 222-232

Mandei, Juliana R, Theodora Katiandagho, Charles R. Ngangi, 2011, Penentuan Harga Pokok Beras Di Kecamatan Kotamobagu Timur Kota Kotamobagu, ASE - Volume 7 Nomor 2, Mei 2011: $15-21$

Mohaddesi, A. et al. (2011) 'Effect of different level of nitrogen and plant spacing on yield, yield components and physiological indices in high yield rice', Amer-Eur. J. Agric. Environ., 10, pp. 893-900.

Pahruddin, A., Maripul and Philips, R. D. (2004) 'Cara tanam padi sistem legowo mendukung usahatani di Desa Bojong, Cikembar, Sukabumi', Buletin Teknik Pertanian, 9(1), pp. 10-12.

Rahman, Benny, 2009, Kebijakan Sistem Pengelolaan Irigasi : Kasus Provinsi Banten, Pusat Analisa social Ekonomi dan Kebijakan Pertanian, Vol 7, No 1, E-ISSN 2549 - 7278

Sriwinarti, Ni Ketut, 2016, Implementasi Penggunaan Kartu Petani: Sebagai Media Pengendali Distribusi Pupuk Bersubsidi, Proseding Seminar Nasional Teknologi Informasi dan Aplikasi (SENTIA), Vol 8 A191-195, Politeknik Negeri Malang.

Wang, K. et al. (2013) 'Quantification of border effect on grain yield measurement of hybrid rice', Field Crops Res, 141, pp. 47-54. 